\title{
Anthropocentric Hubris and Ecological Reversal in J.G. Ballard's The Drought
}

\author{
Rebati Adhikari \\ Independent Researcher \\ Kirtipur Municipality-2, Kathmandu, Nepal
}

Corresponding Author: Rebati Adhikari, Email: adr.rebija@gmail.com

Copyright 2021 ( $)$ Author/s and the Publisher

\begin{abstract}
This paper attempts to analyze anthropocentric hubris and ecological reversal in J.G. Ballard's The Drought by applying ecocritical perspective. In the context of growing environmental concern in literary studies, this paper aims to investigate how the humannature relationship is presented in J.G. Ballard's The Drought. The book depicts a hypothetical world turning into a global desert due to human- induced climate change. The industrial waste released into the rivers and seas has interrupted the evaporation cycle. As a consequence, all lives including humans and non-humans are threatened. To analyze this novel, the ecocritical insights developed by Lawrence Buell, Lynn White, Val Plumwood and Vandana Shiva have been used as theoretical parameters.

Unquestionably, this novel strives to cultivate environmental consciousness among readers and greater urges to save the planet by projecting the futuristic apocalyptic scenarios and situating all biotic and abiotic components on the verge of extinction. However, this narrative eventually creates a bit of illusion among readers by restoring the hydrological cycle without making characters ecologically aware and morally obliged towards nature. Hence, the researcher believes that until and unless human beings develop ecological self, the avoidance of ecological reversal is unachievable. Keywords: Ecological crisis, industrialization, anthropocentrism, economy, climate change
\end{abstract}

\section{Introduction}

Currently, the globe is witnessing environmental fragmentation. Undeniably, the interruption of humankind to nature is excessive. The predominant human-centered worldview which we call 'anthropocentrism' has challenged the whole web of life. Gavin Rae defines anthropocentrism as "the belief that human beings exist at the center of existence" (1). Anthropocentrists regard other things as being instrumentally valuable, i.e. valuable only to the extent that they are means or instruments which may serve human beings" (Callicott 299). This philosophical worldview gives central importance to human beings. Hence, humankind has developed a hubristic attitude. Hubris signifies the dangerous combination of over-confidence, over-ambition, arrogance and pride (Diamandis and Nick Bouras 2). Regarding this, William Cronon articulates "To think 
ourselves capable of causing "the end of nature" is an act of great hubris, for it means forgetting the wilderness that dwells everywhere within and around us" (117). The hubris stimulates human beings to thrash the planet to the extent of collapse of human civilization. The hubristic tendency of human beings has been found to be exponentially threatening the whole biosphere since the past few decades. Living Planet Report 2020 reveals:

In the last 50 years our world has been transformed by an explosion in global trade, consumption and human population growth, as well as an enormous more towards urbanization. Until the 1970s, humanity's ecological footprint was smaller than the earth's rate of regeneration. To feed and fuel our 21st century lifestyles, we are overusing the earth's bio capacity by at least 56\%. (6) It is observed that the post-war gave rise to industrialization, science and technology especially after 1970s with the introduction of different agricultural pesticides, the development of nuclear weapons, the advancement of nuclear energy and the invention of biotechnologies. It was the period of heightening economic expansion. Indeed, it is the humans' imprudent desire for accumulating economy, power and progress that destabilizes the ecological balance. Subsequently, the entire biota is losing its organicity.

The unnatural treatment of human beings to nature has endangered all biotic and abiotic components including, human beings, plants, animals, microorganisms, and genes. The Living Planet Report discloses that one million species including animals, plants and insects are threatened with extinction over the coming decades to centuries (12). It shows that the earth is probably going to experience the sixth mass extinction in near future. Despite the continual warning from the scientific community, the excessive mastery over nature has not been lessened and even more accelerating owing to the fact that the anthropocentric worldview is highly pervasive in this modern era. In November 1992, the Union of world scientists had responded to the global ecological crisis as the consequence of humans and warned humanity to control their ecologically unfriendly behavior. In the words of those scientists "we the undersigned, senior members of the world's scientific community, hereby warn all humanity of what lies ahead. A great in our stewardship of the earth and the life on it, is required, if vast human misery is to be avoided and our global home on this planet is not to be irretrievably mutilated" (3).

People are shutting one's eye to the forewarning of scientists and striving for creating a humanized world with the mechanization of the natural world. Indeed, the hubristic tendency of human beings enlivens the utopian dream

In the context of rising different reactions against environmental crises in environmentalism and environmental criticism, this paper investigates how the narratives of the mid-20th century reflect the contemporary ecological issues and human-nature relationships. For this examination, J.G. Ballard's The Drought' has been taken. Similarly, the past studies on this novel mainly rely on the impact of environmental catastrophe on human civilization while the nonhumans' aspects are highly neglected. In this stance, this study attempts to encompass both humans and nonhumans. Mainly, this study centers on two research questions: how does this novel demonstrate the human-centered behavior? And what are its impacts on ecology including biotic and abiotic worlds? Taking these research questions into consideration, the researcher aims to examine human-centered behavior and its impact on the whole ecological community in the novel. 


\section{The Drought as Ecological Narrative}

As portrayed in other ecological dystopian narratives, The Drought attempts to make the readers realize that the end of the world is near due to the moral degradation of human beings. Rudolphus Teeuwen expresses "In ecological dystopias the end of the world is near and human beings need to be taught humility in order to prevent the collapse of the planet. This humility requires human beings to see themselves in a wider context of beings - animals, vegetables, and minerals — sharing our planet” (41). The Drought offers a mirror to the whole humankind to acknowledge their flaw. It unmasks the human centered behaviors of the modern age that could ultimately ruin the world. Based on the anthropocentric worldview of the mid-20th century, Ballard demonstrates the worsened future world characterized by immoderate drought as a consequence of anthropogenic climate change. The society that appeared after the industrial revolution possessed an anthropocentric vision, where all life on the earth was centered on man (Agner 197). The natural elements were central to the global economy. The World Economic and Social Survey 2017, reviews the global economy since 1957 and identifies the period of 1945 to 1970 as the 'Golden age of capitalism'. This period marks the achievement of a high and sustained level of economic growth (24). By the mid-1950s postwar, the world economy entered a period of unprecedented output and trade expansion. New technologies were introduced and international trade was liberalized (World Bank 43). With respect to the post-war economy and environmental crisis, an environmental activist, Vandana Shiva expresses "After World War II, agrochemicals like fertilizers, pesticides, herbicides were excessively used for more production and enormous profit. This industrial agriculture began to erode biodiversity with the extinction of species, disruption of climate systems, desertification of soil and destruction of water systems (2). The Drought captures the contemporary reality of economic boom and industrial expansion that had highly heightened the environmental pollution.

Industrial society of The Drought makes a choice of economic progress rather than a well-being of the whole biosphere. Here, a prominent figure of ecocriticism, Lawrence Buell's idea of 'environmental apocalypticism', is relevant to justify the human-nature relationship in the novel. Buell interprets nature as the most powerful master metaphor (285). He writes, "In western culture, the order of nature has been variously imagined as, for example, an economy, a chain or scale of being, a balance, a web, an organism, a mind, a flux, a machine (280). Western culture has tremendously impacted the globalization process. Lynn White Jr. asserts that the leadership of the west, both in technology and in science, is far older than the so-called Scientific Revolution of the 17th century or the so-called Industrial Revolution of the 18th century (41). The Drought reflects the dominance and leadership of the west in the worldwide economy and its impact on the global environment. In this novel, the order of nature has been primarily imagined as an economy. Industrialization is a means of attaining economic growth. In this run, nature has been treated as an inanimate object and an instrument. Buell asserts that nature is transformed into a modern corporate industrial system (283). Admittedly, the industrial enterprise has highly contributed to the environmental devastation in the novel by turning extreme weather events through hazardous greenhouse emissions. Thereby, each component of nature is transfigured. Buell admits that our choice of one metaphor can invite disastrous consequences (281). Assuredly, the world is experiencing a disastrous drought in the novel because of humans' choice of economic expansion and industrial intervention in nature.

In The Drought, nature is alleged as an unlimited sink of human-generated pollution. Nature is turned into the disposal of anthropocentric emission. The vast 
quantities of greenhouse emissions are released into the air, river, ocean and soil. Ballard writes "millions of tons of highly reactive industrial wastes-unwanted petroleum fractions, contaminated catalysts and solvents -were still being vented into the sea, where they mingled with the wastes of atomic power stations and sewage schemes" (31). Not only industrial wastes, other forms of human-generated pollution like nuclear wastes and sewerage are equally polluting the water resources. It has prevented almost all evaporation of surface water into the air space above. The disturbance in the hydrological cycle has contributed to the increment in global temperature. In addition, enormous smoke is produced by the fires of incinerators and abandoned garbage contributing to air pollution (Ballard 34). Lawrence Buell makes the prediction about the doomsday in consequence of the excessive interruption of chemical industries and nuclear warfare on nature. As Buell forecasts, the earth is experiencing the adverse effects of climate change resulting from the release of radioactive greenhouse emissions into nature and nuclear wastes in the novel. Climate change has led to excessive drought in Hamilton city and has imperiled each particle of the earth. Verily, every single scenario of the novel is completely pessimistic that signals ecological fragmentation.

Nature has lost its organic meaning in The Drought. Self-regulating system of nature has been disturbed. Primarily The Drought exaggerates what would happen if human beings cross normal limits or human-centered behaviors carried to extremes. The gloomy picture of the world has been sketched throughout the novel. The utmost rise of global temperature has an adverse effect on each particle of the earth including air, water, soil, plant, terrestrial, marine and aquarium lives. The diminution of rainfall, continued fall of the river, lost spirit of river and transformation of the lake, illustrate the disturbances in the self-regulating system of water. Ballard calls 'the death of river' for shrinkage water level. Similarly, the industrial wastes, smoke of garbage and incinerators fire, smells of unburied sewage have serious implications in the air quality. Likewise, the draining creeks, mudflats, dust, deserted wharfs show the declination of soil's natural form (Ballard 1-11). In the same way, varieties of plants like the avenues of miniature palms and rhododendrons are on the brink of extinction (23). As a whole, the richness of nature has been interrupted, reduced and transformed in the novel. The restoration of nature is a longer process. Once degraded nature cannot heal itself immediately.

The earth is a common habitat and life source for all organisms. If nature is violated, each organism is equally affected. In The Drought, all life forms are endangered. The aquatic and marine lives have lost their habitat due to radioactive and fall of water. Everywhere the sand is merged with the fine bones of thousands of fish, the white flakes of mollusk shells (Ballard, 137). There are no fish in the river. Similarly, swans and geese are dying and some are suffocating in oily water (1-11). Pollutants discharged from the industries have not only widespread implications on the river but also on the ocean. The ocean is acidified which is home to a vast and diverse range of organisms. Ballard describes how human-produced pollution change the natural ocean as

Covering the off-shore waters of the world's oceans, to a distance of about a thousand miles from the coast, was a thin but resilient mono-molecular film formed from a complex of saturated long-chain polymers, generated within the sea from the vast quantities of industrial wastes discharged into the ocean basins during the previous fifty years. This tough, oxy-gen-permeable membrane lay on the air-water interface and prevented almost all evaporation of surface water into the airspace above. Although the structure of these polymers was quickly identified, no means was found of removing them. The saturated linkages produced in the perfect organic bath of the sea were completely non-reactive, 
Anthropocentric Hubris and Ecological Reversal 98

and formed on intact seal broken only when the water was violently disturbed.

(31)

Pollution has altered the organic form of the ocean. As a result, the lives associated with water sources are threatened to a greater degree.

In The Drought, the transformation of nature has affected terrestrial lives as well to a larger extent. Due to extreme temperature and starvation, domestic animals like cattle are dead (Ballard 86). Birds and monkeys have disappeared (50). Accordingly, lions are in the state of vanished (130). It shows that the world is facing the fragmentation and acceleration of species extinction largely due to the loss of nature. No one is inviolable from the disaster including human beings. Due to the hubristic tendencies, humans have invited self-destruction. In The Drought, the human induced drought has threatened human civilization as well. Timothy W. Luke expresses "By fooling with nature in this way, we also are foolishly harming ourselves" (16). In the same context, Bill Devell and George Sessions opine that no one is saved until we are saved (67). Harming the oceans and rivers, Hamilton people have called upon selfdestruction. The lakeside town has vanished (Ballard 147). This disaster causes several human deaths. Moreover, the survivors are coping with different challenges including scarcity of drinking water, starvation etc. In addition, the drought has caused physical and mental change in major characters including Ransom, Mr. Quilter, Mrs. Quilter, Philip Jordan, Catherine, Miranda etc. Ransom's hair has been bleached almost white by the excessive sunlight. Mrs. Quilter also has faded red hair and grotesque appearance. Ballard describes the physicality of Quilter as “Quliter's great eyes below the hydrocephalic forehead, deformed skull, caliban-like appearance, cheekbones were set back two or three inches, leaving deep hollows below the eyes” (Ballard 9-10). Likewise, Miranda Lomax is prematurely aged (44). All these major characters have some forms of mental or psychological disturbances as well. Dr. Ransom tries to cut off himself from the rest of the world. Similarly, Quilter has an obsession with water and behaves like a maniac. Accordingly, Mrs. Quilter runs insane and mutters at the people going down to the water's edge with a bucket (9). It shows that human life can be sustained only in a healthy ecology. Environmental degradation deteriorates the quality of human life and may lead to extinction as well.

It is the responsibility of human beings to save the planet. However, Ballard's characters do not show even a small effort to rebuild nature. Culture may be a reason for this dereliction. Human beings and culture are intertwined. Culture shapes the ecological behaviors of humans. Despite experiencing a tremendous ecological crisis, human beings jeopardize their lives in the view of the fact that the hierarchical structure is profoundly embedded in the culture. For this reason, Lynn White suggests a cultural remedy. According to White, anthropocentrism is deeply embedded in the culture especially in the western form which is the most predominant culture in the world (White 43). Regarding the relationship between humans and culture, Val Plumwood asserts that culture treats the relationship of human/nature as a dualism that underlies the environmental crisis (2). Plumwood further asserts that nature has been stereotypically represented in the culture. Ballard's characters, mainly Dr. Ransom, the protagonist of the novel, maintain his hubristic attitude even in the state of hard times. Ransom justifies the human and nature relationship with binary opposition as "remember, though that here, unlike the world outside, you still have bars between you and the animals" (52). Ransom creates a hierarchy among humans and non-humans. He does not observe the world as a whole rather believes in human supremacy. It shows that the rationalist culture is still alive in the deserted Hamilton city. Plumwood alludes "rationalist culture has fostered a version of self-enclosure and human centeredness (98). Dr, Ransom 
exhibits self-centeredness. When Philip Jordan approaches to wash the oil-covered swan, Ransom tries to stop him saying "Philip, I can't spare the water. The bird is almost dead" (Ballard 21). He lacks moral obligation towards nature. For him, humans are the most important life form in this universe. Actually, he lacks interconnectedness, conflation and biotic egalitarianism. These modes of perception are suggested by Lawrence Buell to avoid imminent peril. Though Ransom is the protagonist of the novel, his role is not influential. Admittedly, he does not persuade the readers as an ideal figure nor does he contribute to developing the ecological self.

\section{Humans and Ecological Crisis}

Not only the protagonist, but also other major characters of The Drought lack ecological wisdom. Richard Foster Lomax represents the corporate world that tries to colonize nature. Indeed, in a capitalist economy, natural resources are controlled, seized, over consumed and exploited. Natural resources refer to oil, minerals, forests, water, and fertile land that can be exploited for economic gain. These resources frequently represent an important source of income and power (DPE and UNEP 11). Lomax captures the remaining water, while other ordinary people are battling for drinking water and other environmental ruin. Even so, he has a luxurious house with a private swimming pool with a fountain (Ballard 27). Furthermore, he wants everyone to depart for the coast thereby he can capture all resources. The effect of globalization and its strategy to control the global economy also can be observed in Lomax. An anti-globalized author, Vandana Shiva argues that "Globalization is restructuring the control over resources in such a way that the natural resources of the poor are systematically taken over by the rich ...” (467). The novel demonstrates the economic dictatorship of Lomax. Regarding this, Cenk Tan argues that Richard Lomax is guided by a greedy free-market mentality that prioritizes material wealth above anything else (103). Lomax also reflects the post-war trend of the political system and propaganda. He propagandized that there is a future on the coast. He creates an illusion among people for the end of self-interest and pursuit of profit. Tan asserts that capitalism inevitably leads to the destruction of nature, no matter how or when (100). Truly, the corporate leadership denies the earth democracy. The earth democracy regards the earth as a community and advocates that nature is not an object of ownership, manipulation, exploitation or disposability (Shiva 9-11). Ballard's character Lomax does not represent universal interest, rather he thinks about his own benefit and strives for possession of natural resources. He lacks the sense of biotic egalitarianism. Indeed, greed and self-centeredness lead the earth towards nowhere except annihilation.

Richard Lomax affirms his superiority over nature. Lomax approaches selfdestruction by creating hierarchical human-nature relationships. In the words of Dr. Ransom, Lomax is a menace on his own (51). He does not believe in dynamic equilibrium in the ecosystem that sustains ecological balance. The ecological balance maintains the entire biota and establishes a healthy environment (Verma 159). The Drought advances, "While talking about the entire balance of nature, Lomax snapped his fingers irritably. 'Don't talk to me about the balance of nature! If it wasn't for people like myself we'd all be living in mud huts” (Ballard 42). Lomax holds extreme pride and behaves as if nature is his private property. Here, the mud hut symbolizes an eco-friendly medieval period. Regarding this, Lynn White proclaims that man's relation to the soil was harmonious in the medieval period. As time advances, man's relation with soil profoundly changed. Formerly man was part of nature, now he is the exploiter (42). In the novel, the mud hut is replaced by Lomax's concrete mansion. He feels pride in subverting the man's relationship with soil. Moreover, his artificial swimming pools 
contribute to the loss of natural beauty and its organicity. There is no longer a natural environment in the novel. In reality, man's relationship with nature has transformed. Moreover, Ransom contemplates that Lomax does not have love, pity and moral obligation towards animals rather he possesses hidden interest. When Lomax assists the zoo with water, Ransom supposes that Lomax hasn't given the water to the zoo out of charity; he obviously intends to use the animals for his own purposes (51). This statement of Ransom contributes to justify the anthropocentric attitude of Lomax. In actuality, Lomax is guided by human-centered ethics. Human-centered ethics refers to the human's responsibilities towards non-human world based on the well-being of human beings (Taylor 74). Being a local authority, Lomax pretends to be a loyal and kind personality. His charitable donation of water to the zoo demonstrates his hidden political interest. Indeed, the dominance of corporations is contributing to the global ecological crisis.

In The Drought, the sequences of deadly events are portrayed as if the end of the world is near. Notwithstanding, it speculates a hope of ecological recovery or selfhealing potency of nature at the end. Falling of a few drops of water seemingly symbolizes hope. To a substantial degree, this novel has an impact of Christianity. Rising temperature and spreading fire echoes the biblical belief that the world will be ended by fire. The Book of Revelation reveals the end of the present world and the coming of a new age. In Revelation, the vision of the future amplified by John as

I saw a new heaven and a new earth; for the first heaven and the first earth had passed away.... And I saw the holy city, the new Jerusalem, coming down out of heaven from God,... he will wipe every tear from their eyes. ... . Death will be no more; mourning and crying and pain will be no more, for the first things have passed away. ... I am the Alpha and the Omega, the beginning and the end. To the thirsty I will give water as a gift from the spring of the water of life. (21: 1-6) The Revelation does not suggest the complete destruction of the world rather it creates hope among people. The ending of The Drought "Although it was not yet noon, the sun seemed to be receding into the sky, and the air was becoming colder. ... It was some time later he failed to notice it had started to rain" resembles the revelation of John "To the thirsty I will give water as a gift from the spring of the water of life". Though the pessimistic scenarios are exaggerated throughout the novel, it ends with a promise. It shows that the novel does not fully convey the ecological warning rather it communicates whatever the worst today is, a beautiful day is waiting for us.

Moral obligation towards nature is crucial for nature preservation. The literary studies should communicate moral messages to the readers in order to enlarge responsibility towards nature around them. Nevertheless, Ballard's characters lack ethical accountability towards nature. They dream of a new world without any endeavors. Otherwise stated, these characters respond to the ecological crisis with a utopian perspective. Leonard Orr opines that “Ballard's characters are those who will not evacuate from the approaching floods, the growing deserts or from being turned into crystals and they will stay until they see their assimilation into this new world as growth and achievement” (483). It shows the influence of Christianity on these characters. They acknowledge what disaster comes before them and await a privileged future. Dr. Ransom waits for the evacuation of the city. He seems convinced that the city will vanish for good (Ballard 7). Similarly, Quilter believes that there will be no crisis in the future and there will be much water (54). In the same way, Catherine has a hope that it might rain tomorrow (52). In a like manner, Jonas looks for a new river (61). Moreover, Miranda and Quilter are compared with two biblical figures Adam and Eve who are waiting for time's end when these two characters sit together in the concrete pool (168). 
Another important character Johnstone seems optimistic for a promising future. Johnstone literally represents the true follower of Christianity. He expresses "you know, I sometimes think we ought to accept the challenge and set off north, right into the centre of the drought,...there is probably a great river waiting for us somewhere for there, brown water and green lands” (71). All in all, these Ballard's characters never give up hope whatever the circumstance is. In the beginning, Hamilton city is inhabitable for human civilization due to the scarcity of water, so they leave for the coast hoping that there might be a better world. Again, they keep struggling on the coast. When they find the coast disastrous and unfit for human civilization, they get back to their hometown after ten years hoping their town might be reconstructed. The characters are presented as only witnesses to the catastrophe rather than fighters. Indeed, human-nature co- participation is lacking in the novel. All things considered, The Drought does not prescribe the appropriate ethical response to the characters to avoid the disaster. The characters seem religiously governed especially in western form. As Lynn White suggested, Hamilton city is in the need of a religious remedy to respond to the ecological crisis.

\section{Conclusion}

After examining the context, setting, characterization and author's message, it is observed that the human-nature relationships in The Drought are hostile. Humans have explicitly attempted to change the natural order of things for their economic benefit and power manifestation. Humans treat nature as an inorganic entity and invite self-downfall because of their extreme pride in being capable of manipulating nature. As a result, all biotic and abiotic components are equally threatened and are in the state of extinction. Though the novel strives to cultivate environmental consciousness among the readers by projecting the series of futuristic apocalyptic scenarios, it seems a bit fruitless to cultivate an ecological self. The ending of the novel stimulates the anthropocentric worldview rather than imparting a persuasive moral lesson to the readers. On one hand, the major characters lack ecological self and life-centered environmental ethics while on the other hand, the novel inflames the biblical belief about the hope for a new world. It highlights the self-healing capacity of nature and the possibility of the restoration of the ecological cycle without any humans' endeavor. In contrast, the researcher argues that human beings should develop ecological self and biotic egalitarianism to avoid the ecological reversal. The blind acceptance of cultural beliefs may sometimes misguide people.

\section{Works Cited}

Agner, Thompson Von. "Post-industrial Society and the Environment a Proposal for Application of Energy." Proceedings of $4^{\text {th }}$ Biennial International Workshop: Advances in Energy Studies: Energy-Ecology issues in Latin America Campinas, edited by Enrique Ortega \& Sergio Ulgiati, Unicamp, Campinas, SP, Brazil. June 16-19, 2004, pp. 197-205

Ballard, J.G. The Drought.Penguin Books, 1968.

Buell, Lawrence. The Environmental Imagination: Thoreau, Nature Writing and the Formation of American Culture. Belknap Press, 1996.

Callicott, J. Baird. "Non-Anthropocentric Value Theory and Environmental Ethics." American Philosophical Quarterly, vol. 21, no. 4, Oct 1984, pp. 299-309.

Devell, Bill, and George Sessions. Deep Ecology: Living as if Nature Mattered. Peregrine Smith Books, 1985.

Diamandis, Eleftherios P. and Nick Bouras."Hubris and Sciences.” F1000 Research, 2018, pp. 1-4, https://doi.org/10.12688/f1000research.13848.1. 
European Science Foundation. "Impacts of Ocean Acidification.” Science Policy Briefing 37, 2009, pp. 1-11.

"Living Planet Report 2020: Bending the Curve of Biodiversity Loss.” WWF, 2020, https://www.zsl.org/sites/default/files/LPR\%202020\%20Full\%20report.pdf.

Luke, Timothy W. "Deep Ecology as Political Philosophy.” Ecocritique: Contesting the Politics of Nature, Economy, and Culture. University of Minnesota Press, 1999, pp. 1-27.

Orr, Leonard. "The Utopian Disasters of J.G. Ballard.” CLA Journal, vol. 43, no.4, June 2000, pp. 479-493.

Plumwood, Val. Environmental Culture: The Ecological Crisis of Reason. Routledge, 2002.

Plumwood, Val. Feminism and the Mastery of Nature. Routledge, 1993.

Shiva, Vandana. "Ecological Balance in an Era of Globalization.” The Globalization Reader, edited by Frank J. Lechner and John Boli. Blackwell Publishing, 2008, pp. 465-473.

Shiva, Vandana. Earth Democracy: Justice, sustainability and peace, North Atlantic Books, 2015.

Tan, Cenk. “An Ecocritical Study of J.G. Ballard's Climate Fiction Novels.” Pamukkale University, 2019.

UNEP. "Natural Resources and Conflict: A Guide for Mediation Practitioners.” United Nations Department of Political Affairs and United Nations Environment Programme, 2015.

United Nations Department of Economic and Social Affairs. "Post-war Reconstruction and Development in the Golden Age of Capitalism." World Economic and Social Survey 2017, 2017, pp. 23-48.

Verma, Ashok Kumar. "Necessity of Ecological Balance for Widespread Biodiversity.”Indian Journal of Biology, vol. 4, no. 2, 2017, pp. 158-160.

White, Lynn Jr. "Historical Roots of Ecological Crisis.” Ecocriticism: The Essential Reader, edited by Ken Hiltner. Routledge Taylor and Francis Group, pp.39-46.

World Bank. "Industrialization: Trends and Transformations." World Development Report, 1987, pp. 38-57. 